\title{
NMR in Analysis of the Nutritional Value of Lipids from Muscles and Livers of Wild Amazonian Fishes with Different Eating Habits Over Seasonal Variation
}

\author{
Banny S. B. Correia, ${ }^{\oplus a}{ }^{a}$ Gilberto G. D. Ortin, ${ }^{a}$ Natalia C. Mor, ${ }^{b}$ Maiara S. Santos, ${ }^{c}$ \\ Raquel S. Torrinhas, ${ }^{d}$ Adalberto L. Val ${ }^{e}$ and Ljubica Tasic ${ }^{\oplus *, a}$ \\ Instituto de Química, Universidade Estadual de Campinas, Rua José de Castro, s/n, \\ Cidade Universitária, 13083-970 Campinas-SP, Brazil \\ ${ }^{b}$ Faculdade de Ciências Farmacêuticas, Universidade Estadual de Campinas, \\ Rua Cândido Portinari, 200, Cidade Universitária, 13083-872 Campinas-SP, Brazil \\ 'Instituto Federal de Educação, Ciência e Tecnologia Fluminense, \\ Campus Bom Jesus do Itabapoana, Avenida Dario Vieira Borges, 235, Parque do Trevo, \\ 28360-000 Bom Jesus do Itabapoana-RJ, Brazil \\ ${ }^{d}$ Departamento de Gastroenterologia, Escola de Medicina, Universidade de São Paulo, \\ Av. Dr. Arnaldo, 455, Cerqueira César, 01246-903 São Paulo-SP, Brazil \\ ${ }^{e}$ Laboratório de Ecofisiologia e Evolução Molecular, Coordenação de Biodiversidade, \\ Instituto Nacional de Pesquisas da Amazônia, Avenida André Araújo, 2936, Petrópolis, \\ 69067-375 Manaus-AM, Brazil
}

\begin{abstract}
Endogenous and environmental factors can influence the lipid contents of fishes among which, in the Amazon River, seasonal dynamics influences stand out. Herein, nine most consumed Amazonian fish species had their lipid composition evaluated in terms of effects of tissue, season and eating habits. Higher amounts of lipids were obtained from fish livers than dorsal muscles. Statistical analysis has shown that Amazonian fishes presented different lipid profiles according to their eating habits, which mainly comprised saturated fatty acids to distinguish detritivorous livers, and linolenic acid, cholesterol, polar lipids for carnivorous and piscivorous fish muscles. Furthermore, in Amazonian fish, some very important lipids for human nutrition were found, such as $\omega-3$ and $\omega-6$ fatty acids whose availability depended on the tissue metabolism and fishes' eating habit along with the seasonal periods. For example, our findings indicated that the piscivorous fish C. monoculus presented higher levels of linoleic acid for livers than linolenic acid and the opposite occurred for muscles. The $\omega-6$ and $\omega-3$ fatty acids ratio was influenced by the season dynamic of the Amazon River and availability of food according to each specific eating habit, pointing mainly to the piscivorous fishes as the healthiest fish for human consumption.
\end{abstract}

Keywords: lipids, Amazonian fish, omega-3 and 6, nutrition, nuclear magnetic resonance

\section{Introduction}

The consumption index of fishes by the Amazon inhabitants is one of the highest in the world. ${ }^{1-4}$ It is estimated as $>50 \mathrm{~kg}$ of fishes per person per year in the Manaus City and as 510-600 g per day in the countryside. ${ }^{5}$ The top ten Amazonian fishes most consumed rankings are: (1) Colossoma macropomum, (2) Semaprochilodus insignis, (3) Prochilodus nigricans, (4) Brycon amazonicus, (5) Cichla monoculus,

\footnotetext{
*e-mail: ljubica@unicamp.br
}

(6) Mylossoma duriventre, (7) Triportheus elongatus, (8) Plagioscion squamosissimus, (9) Piaractus brachypomus, and (10) Pseudoplatystoma tigrinum. The Hypophthalmus edentatus could be added to this list as one with the most peculiar taste dish mainly at Pará State due to its great fat amounts. ${ }^{1,3}$ Indeed, it is an interesting fact that there is a preference for the consumption of a few fish species (100 species), regardless of the fact that over 2,500 fish species live in the Amazon River. Also, the Amazon inhabitants avoid consuming the no-scales fish, which are considered as very greasy and harmful to the health, ${ }^{6}$ in fact, they recommend the eating of piscivorous or carnivorous 
fishes when the person is ill. Therefore, they prefer fat fishes consumption to celebration occasions and some species are consumed with their entire inside content, organs and fish ova as Hypostomus affinis. ${ }^{7}$

Fishes meat is considered as a great source of essential fatty acids, such as docosahexaenoic acid (DHA, 22:6 $\omega$-3) and eicosapentaenoic acid (EPA, 20:5 $\omega$-3) that are recommended to a human diet. ${ }^{8-10}$ These polyunsaturated and very-long-chain fatty acids have been shown to have a positive impact on human health since they can prevent many diseases, including cardiovascular, neurological, autoimmune diseases, and cancer. ${ }^{8,9,11}$

The Amazonian fishes' diet can vary among consuming the living plants (herbivorous), plankton (planktivorous), debris (detritivorous), mud (iliophagous), blood (haematovorous), non-fish animals (carnivorous), fish (piscivorous) or both plants and animals (omnivorous). These feeding niches fluctuate depending on the seasonal dynamics of the Amazon River flooding (distributed in low, rising, high, and falling water periods), once the concentration of river's water favors specific predatory hunting and spatial distribution that imposes new biomes, new habitats, and consequent drastic changes in food sources availability. ${ }^{12-14}$ It is why chemical composition of the Amazonian fish may be significantly variable, once besides the Amazon River Basin harbors the largest worldwide diversity of freshwater fish, including singular native species, the particular ecology of the area provides a varied nutrient source and a challenging environment that can influence the biochemical pattern of inhabiting fishes. ${ }^{2}$

The lipid composition of the Amazonian fish, as well as for all freshwater fish, is rich in fatty acids with high amounts of polyunsaturated fatty acids (PUFA) of type $\omega-3$ and $\omega-6$ and cholesterol. ${ }^{15-21}$ The amounts of fatty acids (FAs) found vary among the freshwater fish, however, they usually present the same FAs, which are those with 14-22 carbons, with saturated and unsaturated chains, and $\mathrm{C} 18$ series show the most variable unsaturation possibilities. The total amount of the unsaturated fatty acids can be higher than the saturated fatty acids sum in many cases, ${ }^{16,22}$ however, the opposite can also occur. ${ }^{17}$ In the majority of papers, only dorsal muscles' lipids were evaluated, although some works ${ }^{18,20-24}$ reported on other tissues' lipids, such as liver, eyeball, and brain.

While wild freshwater fish lipids reports are focused on the fatty acid profiles, the global lipidomes, which could be influenced by several factors, are poorly characterized. Also, many works showed and investigated DHA and EPA as the main bioactive polyunsaturated fatty acids in fish, however, the precursor of these important fatty acids, which are the $\omega-3$ linolenic acid for DHA and EPA, and the $\omega-6$ linoleic acid for arachidonic acid (AA, 20:4 $\omega-6$ ), $, 25,26$ are often set aside in the discussion even if those are more abundant than ones with the longer chains. ${ }^{16}$ Nevertheless, the ratio of linoleic and linolenic acids in fish can indicate their potential to produce EPA, DHA, and AA, besides suggesting how healthy is that food source since the balance between $\omega-6$ and $\omega-3$ must be less than 5:1 to be considered healthy. ${ }^{27}$

Thus, our aims were, by using nuclear magnetic resonance (NMR) spectroscopy, to discriminate the lipid differences of the fish species most consumed by the Amazonian population according to their eating habits and to seasonal variation of Amazon River, and, also, determine linoleic and linolenic amounts in the nine most consumed fishes by Amazonians.

\section{Experimental}

\section{Sampling}

The top nine most consumed species of Amazonian fishes (Colossoma macropomum, Triportheus elongatus, Brycon amazonicus, Prochilodus nigricans, Semaprochilodus insignis, Pseudoplatystoma tigrinum, Cichla monoculus, Hypophthalmus edentatus, and Plagioscion squamosissimus) were collected (approved study protocol by Brazilian Institute of the Environment and Renewable Natural Resources (IBAMA), license No. 29837 and 39985) at the Catalão Lake using the floating base of Ecophysiology and Molecular Evolution Laboratory of National Institute of Amazonian Research (INPA) in six points disposed in Figure $\mathrm{S} 1$ of Supplementary Information (SI): (1) $03^{\circ} 10.570^{\prime} \mathrm{S} 059^{\circ} 55.000^{\prime} \mathrm{W}$; (2) $03^{\circ} 10.736^{\prime} \mathrm{S}$ $059^{\circ} 54.180^{\prime} \mathrm{W}$, (3) $03^{\circ} 09.967^{\prime} \mathrm{S} 059^{\circ} 54.534^{\prime} \mathrm{W}$, (4) $03^{\circ} 09.746^{\prime} \mathrm{S} 059^{\circ} 54.488^{\prime} \mathrm{W}$, (5) $03^{\circ} 10.030^{\prime} \mathrm{S}$ $059^{\circ} 55.579^{\prime} \mathrm{W}$ and $(6) 03^{\circ} 10.437^{\prime} \mathrm{S} 059^{\circ} 54.277^{\prime} \mathrm{W}$. Fishes were captured with sizes bigger than that corresponding to their respective sexual maturity during the Amazon flood (July 08-12) and drought (November 26-29) periods in 2013.

The recommended protocol for euthanasia, using ice and water at $-4{ }^{\circ} \mathrm{C}$, was performed according to national animal care regulations, which was approved by the Ethics Committee on Animal Experiments of INPA under registration No. 026/2015. Samples of muscle and liver were collected using individual scalpel blades and kept frozen at $-20{ }^{\circ} \mathrm{C}$ and transferred to the State University of Campinas (Unicamp) laboratory. The species were identified as described elsewhere, ${ }^{1}$ and grouped by their eating habits as (i) omnivorous, (ii) detritivorous, (iii) piscivorous, (iv) planktivorous and (v) carnivorous. A scheme that illustrates the number of captured fish species and the success of tissue obtaining 
are summarized at Figure S2 (SI section). In summary, a total of 93 specimens of fishes were collected. From those 170 samples were obtained, comprising 93 muscles and 77 livers, in which 70 are from flood period and 100 from drought period.

\section{Lipid extraction}

The dorsal muscles and livers tissues were submitted to protocols for total lipids extraction as described in the literature. ${ }^{28,29}$ Total lipids' extracts were fractionated into three classes of lipids with different polarities as described elsewhere. ${ }^{29,30}$ We have extracted 224 lipid samples from 9 fish species (170 samples of total lipids from livers and muscles and 54 samples of lipids classes from muscles).

All lipid samples were stored at $-80^{\circ} \mathrm{C}$ until analyzed.

\section{NMR analysis}

$5 \mathrm{mg}$ of lipid samples were dissolved in $600 \mu \mathrm{L}$ of 99.8\% deuterated chloroform $\left(\mathrm{CDCl}_{3}\right.$; Cambridge Isotope Laboratories, Inc., Andover, USA) and transferred to NMR tubes $(5 \mathrm{~mm}) .{ }^{1} \mathrm{H}$ and ${ }^{13} \mathrm{C}$ NMR analyses were conducted using a Bruker ${ }^{\circledR}$ AVANCE $600 \mathrm{MHz}$ spectrometer equipped with a triple resonance broadband inverse (TBI) probe. Used conditions for qualitative analysis were: $90^{\circ}$ pulse (zg sequence), pulse power of $27 \mathrm{~W}, 64 \mathrm{k}$ data points, with a spectral width of $12,335 \mathrm{~Hz}$, an acquisition time of $2.66 \mathrm{~s}$, a fixed receiver gain (64), a recycle delay of $2 \mathrm{~s}$, dummy scans of 0 , an accumulation of 56 transients, the temperature of $25{ }^{\circ} \mathrm{C}$. For quantitative analysis $100 \mu \mathrm{L}$ of the standard solution of 1,2,4,5-tetrachloro3-nitrobenzene $\left(5 \mathrm{mg} \mathrm{mL}^{-1}\right.$ ) (Sigma-Aldrich, St. Louis, USA, $99.86 \%$ purity) were added into a solution of $10 \mathrm{mg}$ of the total lipid sample previously dissolved in $500 \mu \mathrm{L}$ of deuterated chloroform $\left(\mathrm{CDCl}_{3}\right)$ with tetramethylsilane (TMS; Cambridge Isotope Laboratories, Inc., Andover, USA). The usual parameters (pulse sequence, pulse power, data points, number of scans) of ${ }^{1} \mathrm{H}$ NMR were the same of the qualitative analysis, the specific parameters were: an acquisition time of $8.19 \mathrm{~s}$, a spectral width of $9.9955 \mathrm{~Hz}$, a recycle delay of $40 \mathrm{~s}$ with a relaxation delay of $48.19 \mathrm{~s}$ (higher than 5 times T1) based on estimated longitudinal relaxation time (T1). ${ }^{29}$ To estimate $\mathrm{T} 1$ initially the pulse of $90^{\circ}$ was calibrated, then it was used the sequence of inversion and recovery pulses; resulting in the $\mathrm{T} 1$ obtained for the slowest signal of interest as $8.69 \mathrm{~s}$. Considering the estimated time multiplied by 5 times in this experiment and the acquisition time (at) equal to $8.19 \mathrm{~s}$, the established recycling time was $35.286 \mathrm{~s}(\mathrm{~d} 1)$ with a relaxation delay of $43.476 \mathrm{~s}$ (higher than 5 times T1).

\section{Data processing}

The obtained ${ }^{1} \mathrm{H}$ NMR spectra (136) from total lipids were referenced to tetramethylsilane, aligned and had their phase-corrected, then binned (0.04 ppm) using MestReNova ${ }^{31}$ and saved as the data matrix, which contained 136 samples by 299 spectra bins. Principal component analysis (PCA) and partial least squares discriminant analysis (PLS-DA) were performed using MetaboAnalyst 3.0 platform, ${ }^{32}$ assuming the parameters as follows: no data filtering, no sample normalization, no data transformation, and Pareto scaling (mean-centered and divided by the square root of standard deviation of each variable).

Five principal components were used for discrimination of the analyzed lipid samples. Specifically, for PLS-DA, we applied leave one out cross-validation (LOOCV) as the cross-validation method. The accuracy and variable importance in projection (VIP) were also assessed to measure the performance and important features for the analysis, respectively. ${ }^{29}$

The levels of linolenic (Ln) and linoleic (L) acids were calculated from the quantitative ${ }^{1} \mathrm{H}$ NMR data according to the method previously reported by others, ${ }^{33}$ where the concentrations of fatty acids are expressed in molar percentages according to the equations 1 and 2 .

$\operatorname{Ln}(\%)=100 \times\left(\mathrm{A}_{\mathrm{Ln}} / 3 \mathrm{~A}_{\mathrm{G}}\right)$

$\mathrm{L}(\%)=100 \times\left(2 \mathrm{~A}_{\mathrm{L}} / 3 \mathrm{~A}_{\mathrm{G}}\right)$

where $A_{L n}$ and $A_{L}$ are the areas of the bis-allylic proton peaks for linolenic $(\omega-3)$ and linoleic $(\omega-6)$ acids, respectively, and $\mathrm{A}_{\mathrm{G}}$ is the area of the proton peaks of glyceryl group.

\section{Results and Discussion}

Lipids of wild Amazonian fishes over seasonal variation

The amounts of lipids extracted from dorsal muscles and livers of nine Amazonian fishes showed to depend on the analyzed tissue, where those from dorsal muscles showed 3-24 mg per $\mathrm{g}$ of the muscle mass (exceptions were planktivorous fish), while total lipids extracted from the livers were in the range of $12-65 \mathrm{mg}$ per $\mathrm{g}$ of liver mass (exceptions were planktivorous fish) (Figure 1). Planktivorous fish showed very close values for lipids, independently from where they were obtained, 88-154 mg per $\mathrm{g}$ of the muscle mass and $85 \mathrm{mg}$ per $\mathrm{g}$ of liver mass.

The studied species of Amazonian fishes presented higher lipid amounts in livers than in muscles, irrespective 


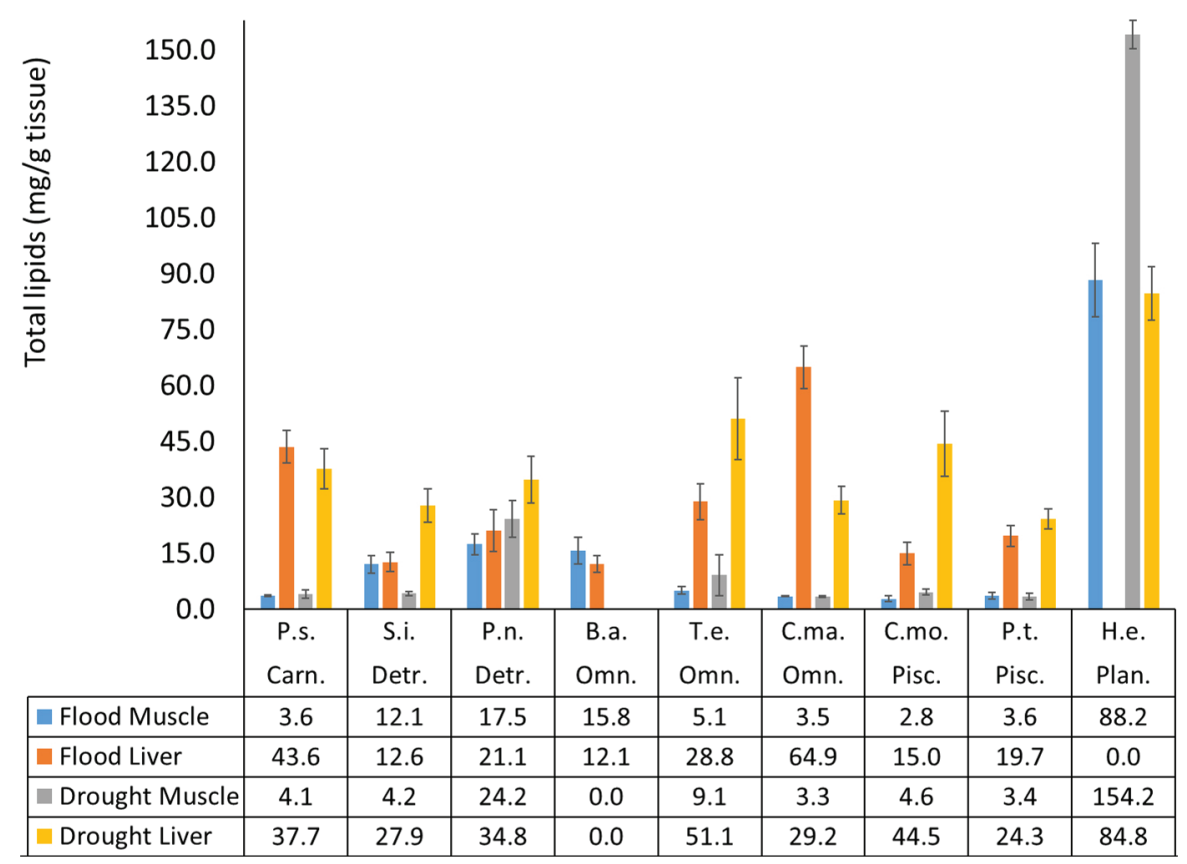

Figure 1. Total lipids of Amazonian fishes with five different eating habits extracted from the dorsal muscle or liver at flood or drought period of Amazon River. P.s.: Plagioscion squamosissimus (carnivorous); S.i.: Semaprochilodus insignis and P.n.: Prochilodus nigricans (detritivorous); B.a.: Brycon amazonicus, T.e.: Triportheus elongatus and C.ma.: Colossoma macropomum (omnivorous); C.mo.: Cichla monoculus and P.t.: Pseudoplatystoma tigrinum (piscivorous); H.e.: Hypophthalmus edentatus (planktivorous).

of the seasonal period. This is coherent with the fact that the liver is a highly metabolic organ. ${ }^{34}$ However, the exceptions were two fish species, B. amazonicus and $H$. edentatus, which presented lower lipid amounts in livers than in muscles.

For the H. edentatus, Carvalho ${ }^{35}$ showed that this fish does not deposit fat, instead the lipids are diffused in the muscular tissue. This fish as well the other studied Amazonian fish species experienced an important change in total lipid amounts of dorsal muscles and livers in response to seasonal dynamics of the Amazon River (flood and drought) among the eating habits. Lipid amounts varied according to the eating habit groups, as follows (from the highest to the lowest levels): planktivorous $>$ B. amazonicus (omnivorous) $>$ detritivorous $>$ omnivorous (except B. amazonicus) $>$ piscivorous $>$ carnivorous for muscles at flood period. At drought season the lipid amounts rankings from muscles presented: planktivorous $>P$. nigricans (detritivorous) $>$ omnivorous $>$ S. insignis (detritivorous) $>$ carnivorous $>$ piscivorous. For livers at drought period, the variation was as follows: C. macropomum (omnivorous) $>$ carnivorous $>$ omnivorous (except C. macropomum) $>$ detritivorous $>$ piscivorous at flood season; planktivorous $>$ omnivorous $>$ piscivorous $>$ carnivorous $>$ detritivorous. It means that in general muscles presented planktivorous as the fattest fish, followed by detritivorous and omnivorous, and as the fish containing less fat, carnivorous and piscivorous took places. These findings are in line with previous studies ${ }^{18}$ reporting the influence of different feeding habits on the total lipid content in fishes and also agree with popular knowledge. For example, H. edentatus is a planktivorous fish and is used as a dish that tastes fat, while piscivorous or carnivorous fishes are preferred and recommend to ill people because those are considered no greasy and good to the health.

An interesting fact is that lipids from carnivorous and piscivorous fish did not suffer an apparent influence of season dynamics, also, the food availability did not affect total lipids contents. However, the distribution of the lipids (types) in studied seasons is an issue to debate. Liver and muscle also may contain different proportions of lipids when classified per their polarities. The lipid class profiles response to the seasonal dynamic in dorsal muscles for the studied Amazonian fishes are illustrated in Figure 2. The higher amounts of phospholipids were found in the dorsal muscle of piscivorous fishes at flood period when compared with samples from the drought period, while the opposite pattern was found for carnivorous specie. The opposite was observed for neutral lipids. Only piscivorous and the P. nigricans (detritivorous) had their phospholipids increased in flood periods, all the other fish species had the neutral lipids increased in flood periods instead of phospholipids. For instance, the abundance of food sources for piscivorous habits occurred during the drought period, which enabled fat storage as neutral lipids. ${ }^{36}$ 


$$
\text { (a) }
$$$$
\begin{gathered}
\text {-Neutral lipid -Glycolipid -Phospholipid } \\
\text { Carn. P.s. }
\end{gathered}
$$

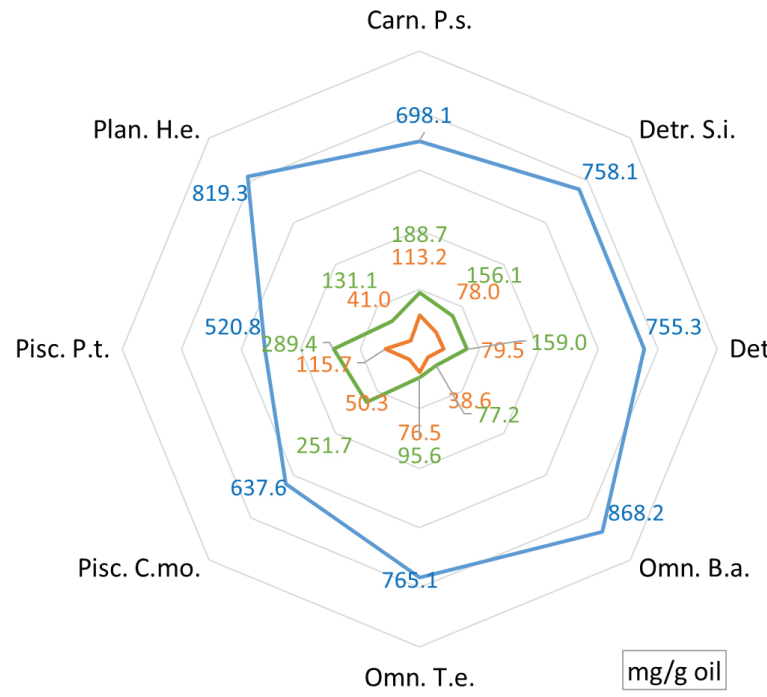

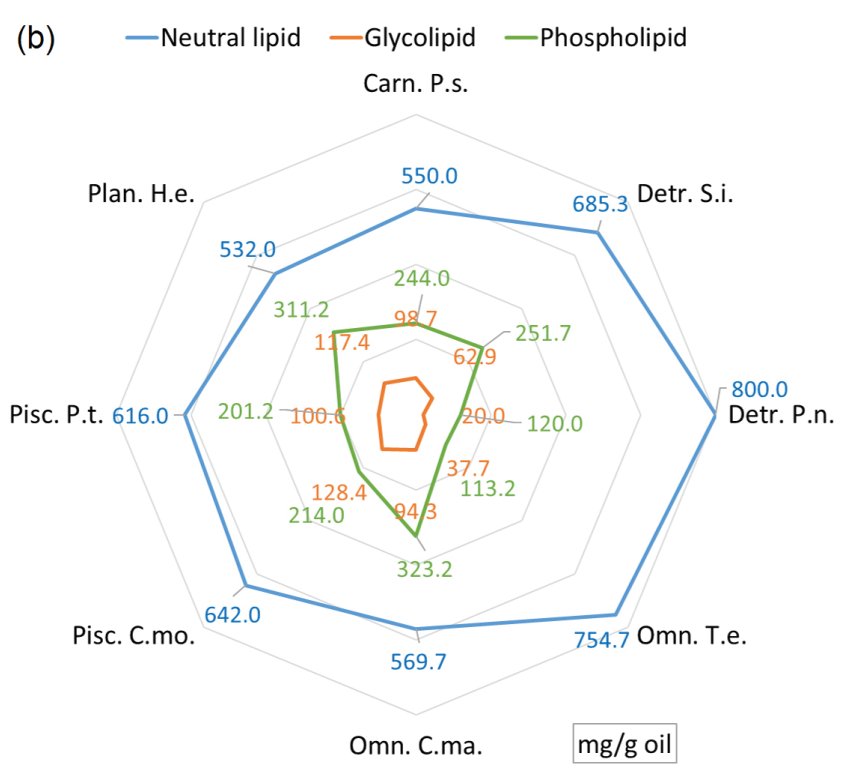

Figure 2. Lipid classes of Amazonian fishes with five different eating habits extracted from the dorsal muscle at (a) flood or (b) drought period of Amazon River. P.s.: Plagioscion squamosissimus (carnivorous); S.i.: Semaprochilodus insignis and P.n.: Prochilodus nigricans (detritivorous); B.a.: Brycon amazonicus, T.e.: Triportheus elongatus and C.ma.: Colossoma macropomum (omnivorous); C.mo.: Cichla monoculus and P.t.: Pseudoplatystoma tigrinum (piscivorous); H.e.: Hypophthalmus edentatus (planktivorous).

Although differences between periods may explain the seasonal availability of food sources, they do not explain detritivorous species lipids distribution as this type of fish shows a quite variable diet. In this way, a distinct seasonal difference in muscle lipid class amounts was observed between the two detritivorous fishes: $S$. insignis presented an increase of neutral lipid content balanced with the decrease of phospholipids in the flood period compared to drought period, while P. nigricans showed the opposite pattern. These findings may be explained by another fact, as the distinct seasonal migratory habits could be the causes of differences in lipids distribution. The $S$. insignis migrates for dispersion in rising water periods and $P$. nigricans in falling water periods. High amounts of neutral lipids may be required for fish migration, as their energy source. It was reported ${ }^{37}$ that dispersal migration of $S$. insignis is characterized by the accumulation of lipids (neutral lipids) while foraging in the flooded forest. Also, it is noteworthy to state that even within a trophic category, there is enough diversity in the diet among the Amazonian fishes, or that it is difficult to classify them by eating habits. The two species S. insignis and P. nigricans are considered as detritivorous, but they also consume genipap fruit at flood period. ${ }^{38}$

\section{Wild Amazonian fishes' lipids identification}

Typical ${ }^{1} \mathrm{H}$ NMR spectrum obtained for lipids extracted from the fish is shown in Figure S3 (SI section). Lipids were assigned according to the reported NMR data..$^{29,39-41}$ The assigned peaks are displayed in Table $1{ }^{42}$
Groupings of the fishes' lipids according to the influences of tissue metabolism, seasonal dynamics of the Amazon River and eating habits through PLS-DA analysis (Figure 3) were able to discriminate endogenous lipid patterns and their correlation with ecological behaviors. The PLS-DA using the ${ }^{1} \mathrm{H}$ NMR spectral data as a matrix showed that the tissue metabolism (Figure 3a) influenced greatly the lipid profiles of the studied Amazonian fishes and more than the seasonal periods (Figure $3 b$ ). This is very obvious when we correlate the studied seasonal periods with each tissue (Figure 3c). In fact, we expected a big difference between the tissues as their specific functions can lead to different lipid composition.

However, the seasonal periods had an important role in distinguishing the lipid profile of the studied Amazonian fishes (Figure 3b), showing that the chemical composition of Amazonian fishes may depend on the seasonal dynamics, which correlates with the type and amount of available food in Amazon River. ${ }^{18}$ Also, the lipid profiles of samples under study were important for separating groups of fishes with different eating habits (Figure 3d) despite the studied seasonal periods for each tissue.

The most pronounced lipid profile differences can be seen in their variable importance projection (VIP) in Figure S4 (SI section), which revealed general fatty acids, linoleic and linolenic acids besides cholesterol and/or polar lipids (phosphocholine, sphingomyelin or saccharolipids) as having higher intensity in muscle samples than in the liver. These differences are assigned, as described in Table 1, by the following NMR signals: 1.24, 5.34, 2.81 
Table 1. Assignment of the main resonances in the ${ }^{1} \mathrm{H}$ NMR spectra of lipids isolated from the Amazonian fishes

\begin{tabular}{|c|c|c|}
\hline Number & ${ }^{1} \mathrm{H}$ NMR chemical shift / ppm & Assignment \\
\hline 1 & $0.75-1.00$ & terminal methyl group hydrogens $-\mathrm{CH}_{3}$ \\
\hline 2 & $0.93-1.02$ & $-\mathrm{CH}_{3}$ hydrogens of linolenyl chain $(\omega-3)$ \\
\hline 3 & $1.20-1.50$ & methylene hydrogens of aliphatic chains $-\left(\mathrm{CH}_{2}\right)_{\mathrm{n}}$ \\
\hline 4 & $1.50-1.75$ & $\beta$-methylene hydrogens of the carbonyl-OCO- $\mathrm{CH}_{2}-\mathrm{CH}_{2}-$ \\
\hline 5 & $1.95-2.10$ & allyl hydrogens $-\mathrm{CH}_{2}-\mathrm{CH}=\mathrm{CH}-$ \\
\hline 6 & $2.20-2.50$ & methylene hydrogens in the carbonyl $\alpha$-position $-\mathrm{OCO}-\mathrm{CH}_{2}-$ \\
\hline 7 & $2.70-2.84$ & $\mathrm{CH}_{2}$-bis-allyllic hydrogens of PUFA chains \\
\hline 8 & 2.76 & diallyl hydrogens $=\mathrm{HC}-\mathrm{CH}_{2}-\mathrm{CH}=$ of PUFA (except linolenic and linoleic) \\
\hline 9 & $2.79^{\mathrm{a}}$ & diallyl hydrogens $=\mathrm{HC}-\mathrm{CH}_{2}-\mathrm{CH}=$ of linoleyl chain $(\omega-6)$ \\
\hline 10 & $2.82^{\mathrm{b}}$ & diallyl hydrogens $=\mathrm{HC}-\mathrm{CH}_{2}-\mathrm{CH}=$ of linolenyl chain $(\omega-3)$ \\
\hline 11 & $3.44-3.59$ & carbinolic hydrogen on $\mathrm{C}-3$ position of cholesterol $\mathbf{C H}$ \\
\hline 12 & $4.10-4.30^{c}$ & Sn-1 and Sn-3 hydrogens of glycerol $-\mathrm{CH}_{2}-\mathrm{OCOR}$ \\
\hline 13 & $5.25-5.50$ & Sn-2 hydrogen of glycerol $-\mathrm{CH}-\mathrm{O}-\mathrm{COR}$ \\
\hline 14 & $5.27-5.38$ & vinyl hydrogens with conformation $Z$ cis $-\mathrm{CH}=\mathrm{HC}-$ \\
\hline 15 & $5.30-5.40$ & $\mathrm{CH}$ of cholesterol relative to the $\mathrm{C}-6$ proton of vinyl \\
\hline 16 & $3.40-3.60$ & hydroxyl hydrogens $-\mathrm{OH}$ \\
\hline \multirow[t]{2}{*}{17} & $3.65-3.75$ & carbinolic hydrogens $(-\mathrm{CH}-\mathrm{OH})$ from carbohydrate \\
\hline & 3.88 & methine hydrogen at $\mathrm{C} 4$ of galactose \\
\hline 18 & 4.00 & carbinolic hydrogens $\beta$ to the amine group $-\mathrm{O}-\mathrm{CH}_{2}-\mathrm{CH}_{2}-\mathrm{N}^{+}\left(\mathrm{CH}_{3}\right)_{3}$ \\
\hline 19 & 3.93 & carbinolic hydrogens $\alpha$ to the amine group $-\mathrm{O}-\mathrm{CH}_{2}-\mathrm{CH}_{2}-\mathrm{N}^{+}\left(\mathrm{CH}_{3}\right)_{3}$ \\
\hline 20 & 5.00 & anomeric carbon hydrogens of galactose \\
\hline 21 & $5.20-5.40$ & amine hydrogen $-\mathbf{H N}\left(\mathrm{CH}_{3}\right)_{2}$ \\
\hline 22 & $3.10-3.20$ & carbinolic hydrogens $-\mathrm{CH}_{2}-\mathrm{OH}$ \\
\hline 23 & $3.20-3.40$ & methyl hydrogens of charged nitrogen $\mathrm{N}\left(\mathrm{CH}_{3}\right)_{3}{ }^{+}$ \\
\hline 24 & $3.50-3.85$ & methylene hydrogens to a charged nitrogen $\mathrm{CH}_{2}-\mathrm{N}^{+}\left(\mathrm{CH}_{3}\right)_{3}$ \\
\hline 25 & $3.90-4.40$ & methylene hydrogens attached to $\mathrm{OP}-\mathrm{CH}_{2}-\mathrm{O}-\mathrm{P}$ \\
\hline
\end{tabular}

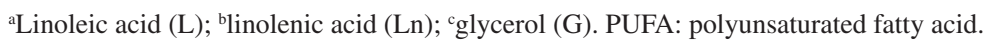

and $2.77 \mathrm{ppm}$ (Figure S4a, SI section). When we observe the season from which the fish samples came from, the lipids from the fish collected in the flood period presented general fatty acids, while the fish lipids from the drought period showed cholesterol and choline based lipids, which were identified as the main differences between the seasons (Figure S4b, SI section). These results are confirmed by the features for muscle lipids from both season periods with cholesterol or polar lipids (phosphocholine, sphingomyelin or saccharolipids), and cholesterol or polar lipids for drought period, which did not depend on tissue type (Figure S4c, SI section). However, the eating habits influences on lipid composition without considering the environmental factors did not present useful information to distinguish the samples, once only general fatty acids were observed (Figure S4d).
By analyzing the separation of season sample type, i.e., drought or flood regardless of tissue factor and considering different eating habits, we have found some singularity to the eating habits comparison (see Figure S5, SI section). Detritivorous habit from both season periods showed similar lipid profiles to omnivorous habit. Carnivorous and piscivorous presented similar lipid profiles, which might point to carnivorous from drought period similarity to piscivorous from flood period and carnivorous from flood period similarity to piscivorous from drought period. Planktivorous fish distinguish from the others responding similarly to omnivorous when caught in flood period, which is the period that omnivorous have their food as seed and fruit more available, and similar to piscivorous when both were caught in drought period once again which is the period that piscivorous have their preferred food most available (other fishes). ${ }^{3}$ 

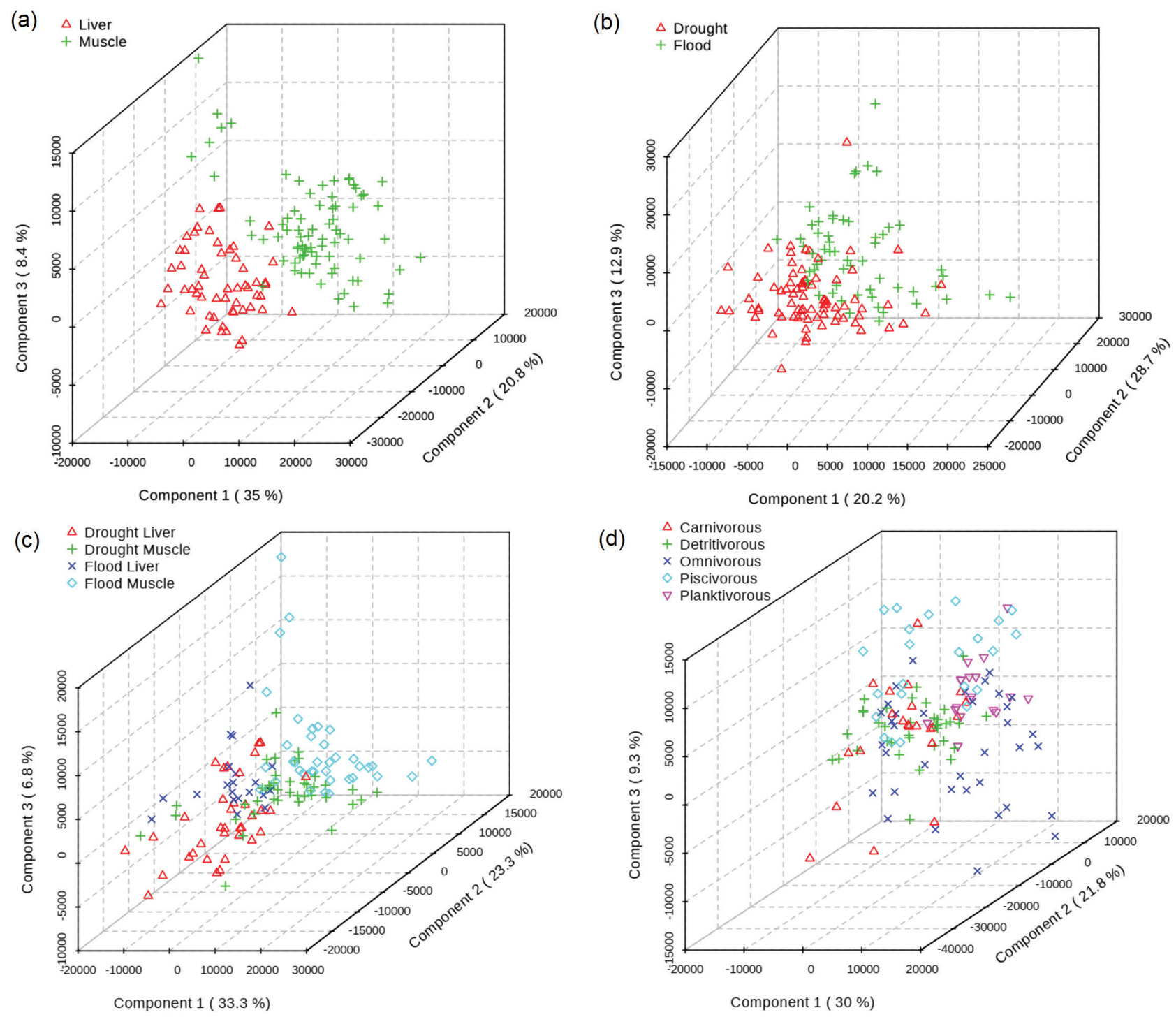

Figure 3. PLS-DA score charts constructed from ${ }^{1} \mathrm{H}$ NMR data of lipids isolated from Amazonian fishes versus (a) tissue (liver or muscle); (b) seasonal period (drought or flood); (c) tissue and seasonal period; (d) eating habit (carnivorous, detritivorous, omnivorous, piscivorous or planktivorous).

Influences on lipids composition and distribution in Amazonian fishes

Many factors can influence the fish lipid profile such as season, tissue, food, and eating behavior (Figure 4). As related in literature, ${ }^{43}$ the season has an effect on the lipids profile of fish. In the drought period, livers were separated in distinct groups in which only planktivorous fish presented slight similarity to those from omnivorous habit (Figure 4a), while muscle from this period had similarity between omnivorous and detritivorous (Figure 4b). At the flood period, the liver presented distinct groups (Figure 4c), and the muscles showed similarity between planktivorous and omnivorous again as at drought period, and between piscivorous and carnivorous (Figure 4d).

The top three features in regard to fish eating habits related to Figure 4 are shown in Figure 5. These results revealed that at drought periods general fatty acids and saturated fatty acids were found in livers (Figure 5a), with more intensity of the response to saturated fatty acids from detritivorous fish, while muscles showed besides of general fatty acids, the linolenic acid and cholesterol or polar lipids (phosphocholine, sphingomyelin or saccharolipids) with higher concentration for carnivorous and piscivorous habit (Figure 5b). At flood periods, general fatty acids were found in both tissues, livers and muscles, as important lipids that distinguished between eating habits (Figures 5c and 5d) with higher intensity for piscivorous fish. Additionally, saturated fatty acids presented a higher contribution to planktivorous fish for muscle.

Therefore, our data suggest that lipid composition of the Amazon fishes can vary because of the fish feeding habits 
(a)

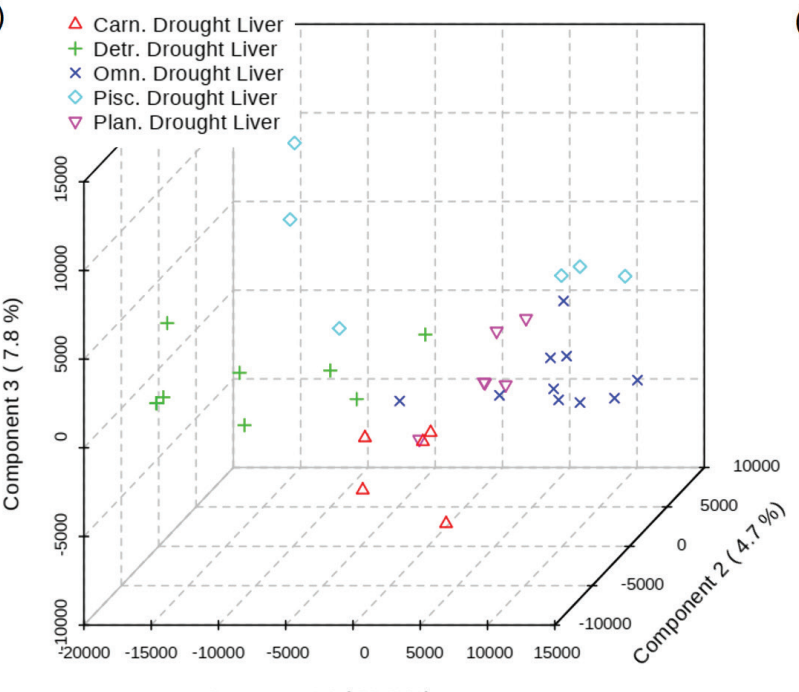

(c)

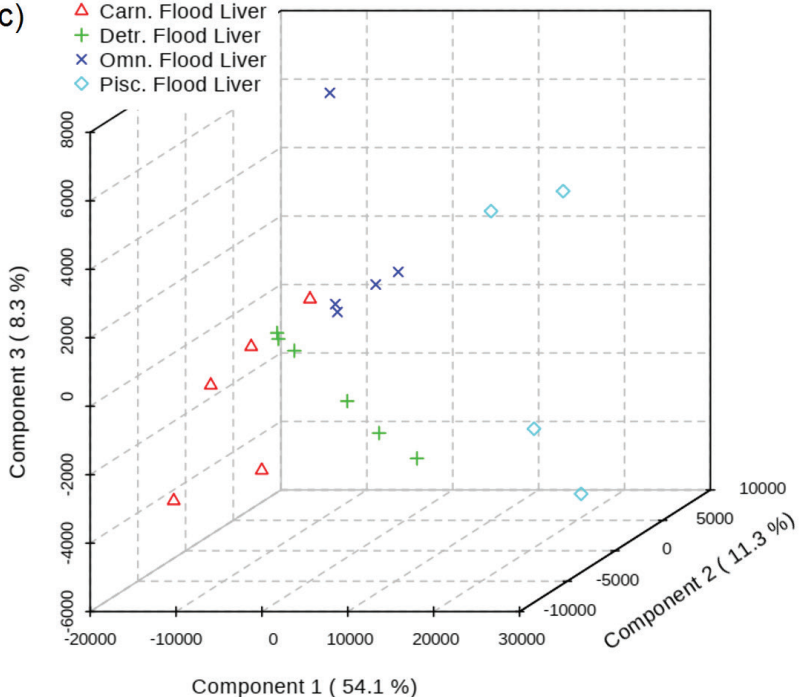

(b)

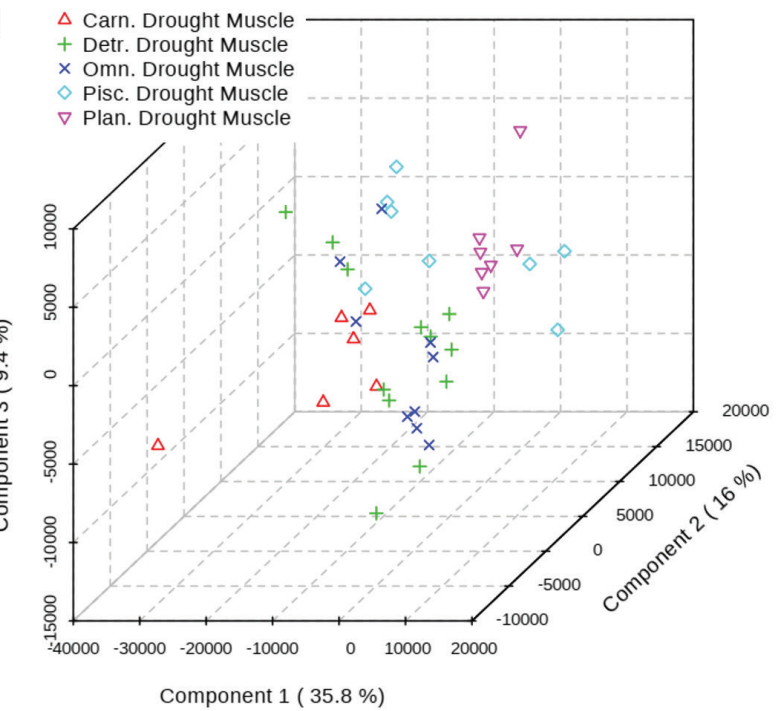

(d)

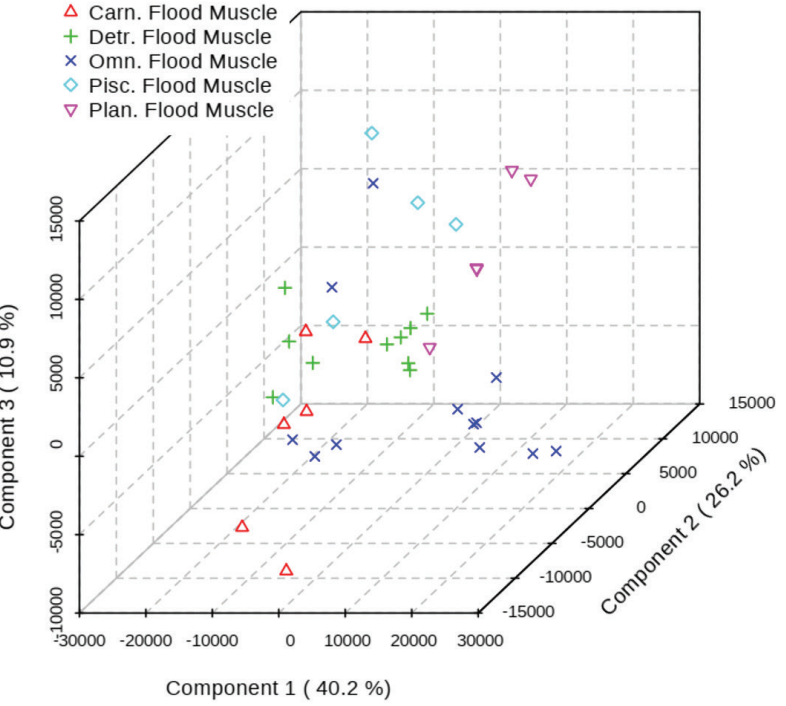

Figure 4. PLS-DA charts constructed from ${ }^{1} \mathrm{H}$ NMR data of lipids isolated from Amazonian fishes versus eating habits showing score of (a) liver from drought period; (b) muscle from drought period; (c) liver from flood period; (d) muscle from flood period.

(mainly in quality), according to the biosynthetic tissue capacity (liver or muscle) to attend the fish individual needs (mainly in amount), which may be influenced by Amazon River seasonal changes.

Linoleic and linolenic acids appeared at muscle tissue being linolenic acid particularly important in drought period in carnivorous and piscivorous habits, which may be presented comprised in phospholipids (phosphocholine, sphingomyelin or saccharolipids) as indicated by polar lipids signals. These habits as mentioned before have their preferred food most available at drought periods which are animals and other fishes. ${ }^{3}$ Although polyunsaturated fatty acids are synthesized by phytoplankton, which is consumed by fish, mollusks and crustaceans (food chain) fishes which consume other fish and/or animals (that are already rich in $\omega$-3 lipids) must be observed in Amazon River as a unique source of bioactive lipids at drought period. ${ }^{44}$ Also, it is not possible to discard the fact that unique lipids may be enrolled in fish adaptation to the challenges imposed by low oxygen availability in this studied season (drought period), for instance. The saturated fatty acids found in muscles of planktivorous fish at flood period seems to point to the production of $\omega-3$ and $\omega-6$ lipids once they (saturated fatty acids) or other functional molecules (dietary carbohydrates, cholesterol, insulin, testosterone and estrogen) may do the role of desaturase enzyme activators; while inhibitors of polyunsaturated fatty acids include the dietary polyunsaturated fatty acids. ${ }^{45}$

\section{Changes in linolenic and linoleic acids amounts}

Amounts of the linolenic ( $\omega-3)$ and linoleic $(\omega-6)$ acids for the studied Amazonian fishes are shown in Figure 6 
(a)

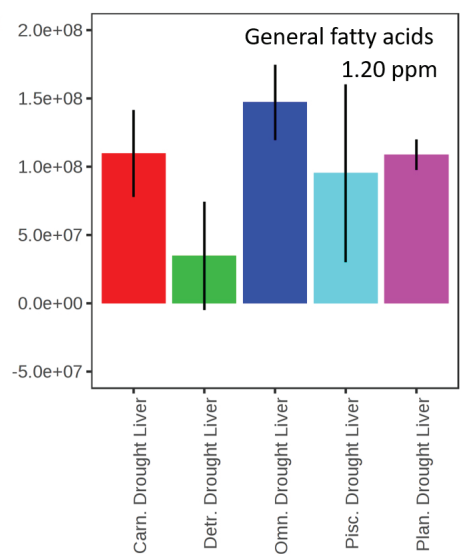

(b)

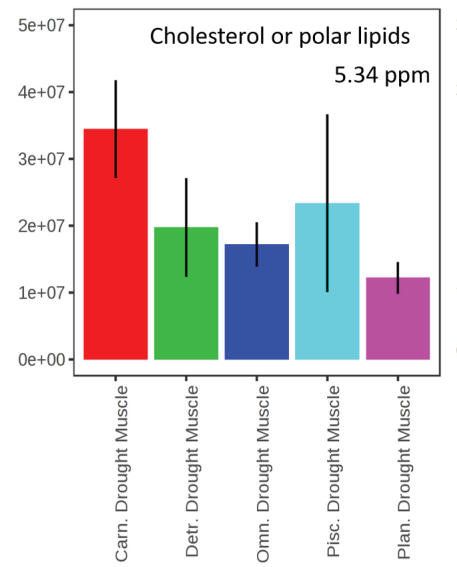

(c)

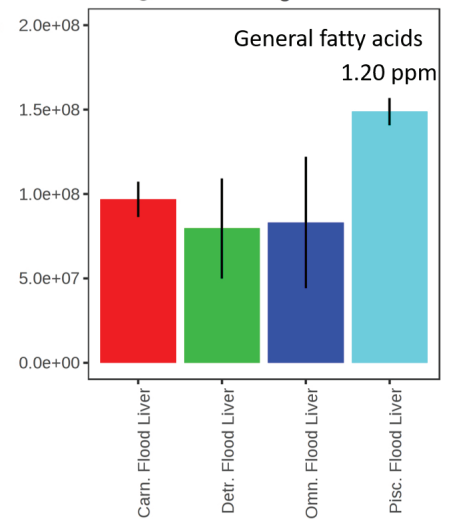

(d)

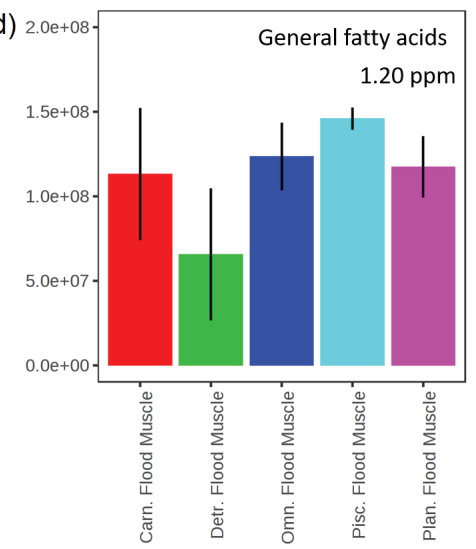

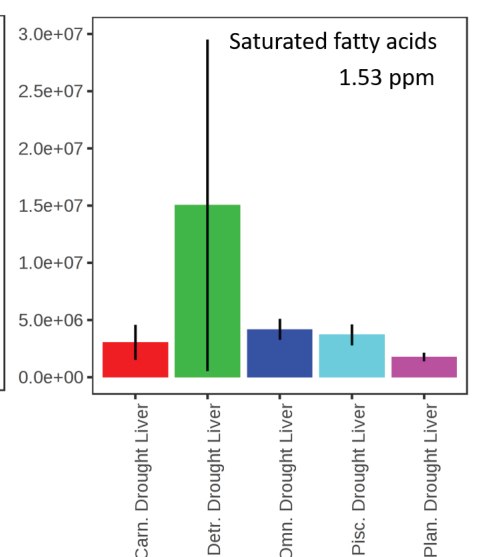
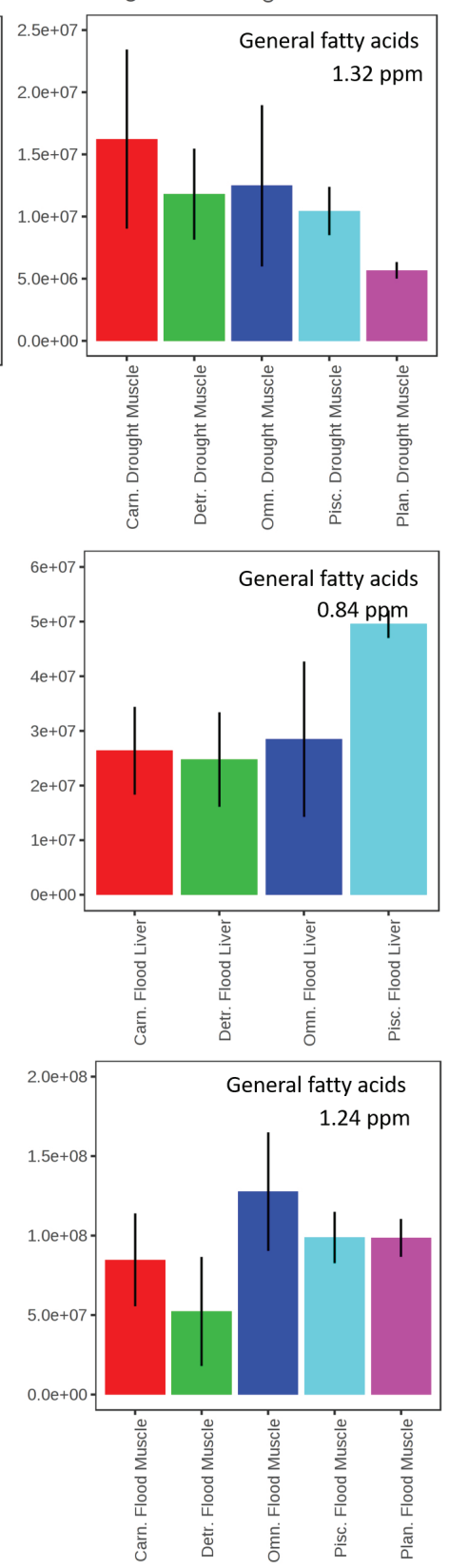

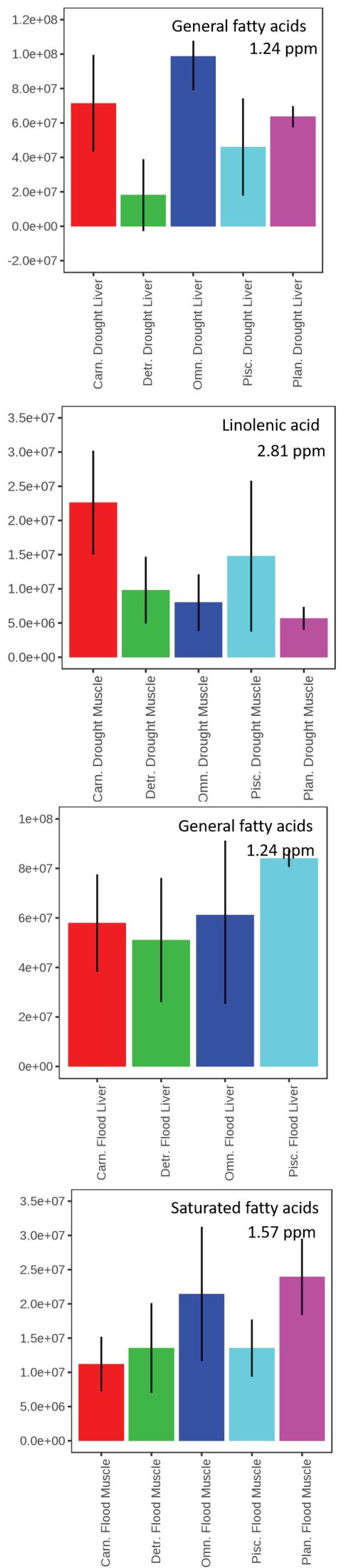

Figure 5. Top 3 feature graphical summary (mean $\pm \mathrm{SD}$ ) obtained for the lipids of Amazonian fishes versus eating habits showing (a) liver from drought period; (b) muscle from drought period; (c) liver from flood period; (d) muscle from flood period. 
as well the $\omega-6 / \omega-3$ ratios based on amounts of these two fatty acids.

The linolenic acid $(\omega-3)$ is the precursor for docosahexaenoic acid (DHA, 22:6 $\omega$-3) and eicosapentaenoic acid (EPA, 20:5 $\omega-3)$, and the linoleic acid ( $\omega-6)$ is the precursor of arachidonic acid (AA, 20:4 $\omega-6$ ). These two PUFA families have been the target of many studies ${ }^{25}$ in recent years since they are biomolecules involved in the regulation of organism functions and present in many foods such as fish. High $\omega-3$ PUFAs consumption is associated with benefits for the prevention or treatment of several diseases, mainly those enrolling in chronic inflammation; while high $\omega-6$ consumption has shown debatable opposite effects. $^{46}$

Many good nutritional habits are based on the use of the two serving portions per week of 250-500 mg of $\mathrm{EPA}+\mathrm{DHA}$ that are considered healthy. ${ }^{47}$

Lipids isolated from muscles from Amazonian planktivorous and omnivorous fishes presented coherent
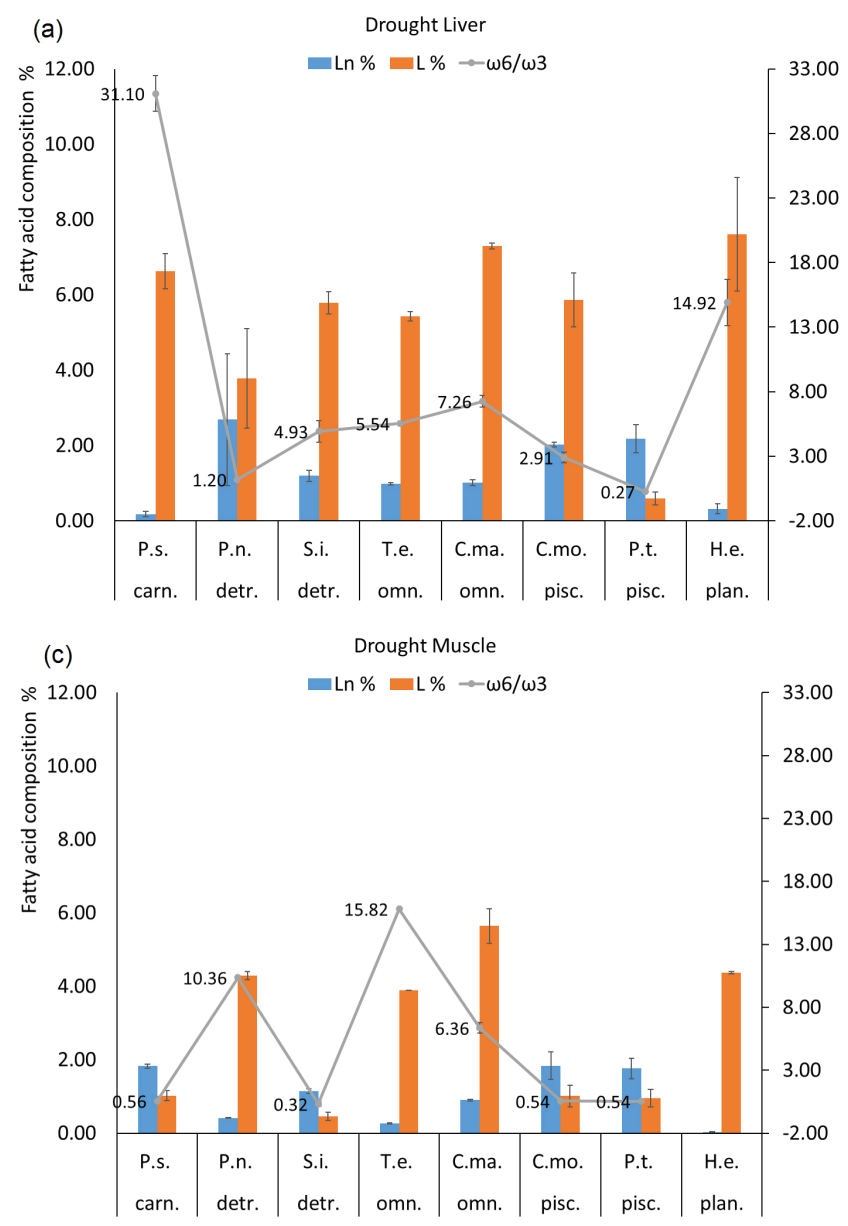

amounts of linoleic acid that were similar to other planktivorous and omnivorous species, respectively, near $6 \%$ to planktivorous and $4 \%$ to omnivorous as compared to Vasconi et al. ${ }^{16}$ work. However, the livers' lipids showed higher amounts (near $8 \%$ to planktivorous, $6 \%$ to omnivorous or $10 \%$ for B. amazonicus in flood season), ${ }^{16}$ while linolenic amounts were lower even in liver samples, ${ }^{16}$ although similar species had lower contents of these as reported in other works. ${ }^{19,48}$ In addition, the Amazonian carnivorous fish showed higher amounts of linoleic acid than other carnivorous species, such as those from South African Cape hake. ${ }^{17}$

Therefore, even rich in linoleic acid, the lipidomes of the studied Amazonian fishes can be recognized as potentially great nutritional sources. Even potentially detrimental, linoleic acid is also the precursor of lipoxins (lipid mediators with a relevant role on the resolution of inflammation) and an adequate $\omega-6 / \omega-3$ ratio can be required for proper immune response. ${ }^{49}$ Importance of the $\omega-6 / \omega-3$ ratio in the diet has
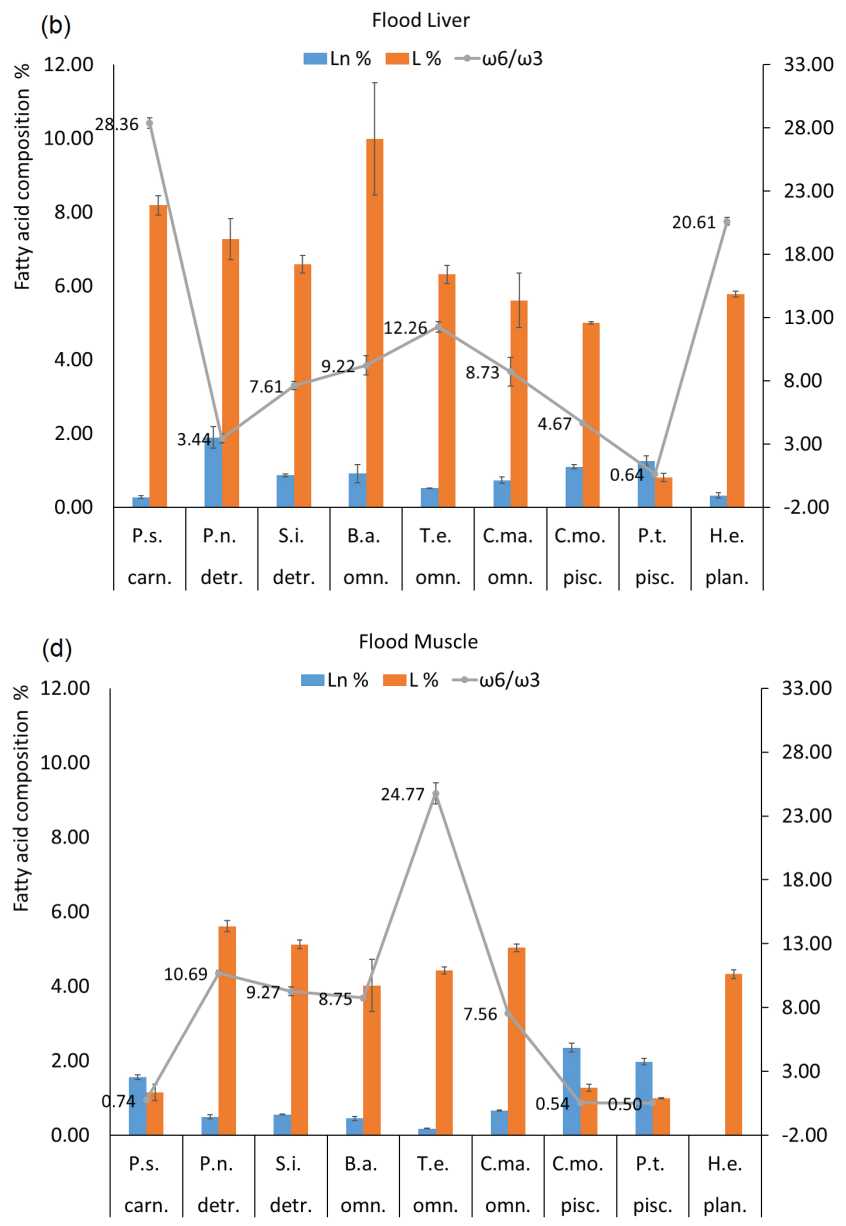

Figure 6. Changes in the fatty acid compositions (percentage of linolenic and linoleic acids) of (a) liver collected in drought period; (b) liver collected in flood period; (c) muscle collected in drought period; (d) muscle collected in flood period of Amazonian fish species classified as its eating habit. H.e.: Hypophthalmus edentatus (planktivorous); P.t.: Pseudoplatystoma tigrinum and C.mo.: Cichla monoculus (piscivorous); B.a.: Brycon amazonicus, T.e.: Triportheus elongatus and C.ma.: Colossoma macropomum (omnivorous); P.n.: Prochilodus nigricans and S.i.: Semaprochilodus insignis (detritivorous); P.s.: Plagioscion squamosissimus (carnivorous); Ln: linolenic acid; L: linoleic acid; $\omega-6 / \omega-3: \omega-6$ to $\omega-3$ ratio. 
been addressed in human nutrition and is considered as healthy when the ratio is $\leq 5: 1 .^{27}$

The species Plagioscion squamosissimus, Prochilodus nigricans, Semaprochilodus insignis, Cichla monoculus and Pseudoplatystoma tigrinum presented $\omega-6 / \omega-3$ ratios lower than 5 in at least one of the evaluated conditions, tissue (liver or muscle) and/or period of the year (drought or flood). It means that the fattest fishes according to the popular knowledge of taste which are the species $C$. macropomum, T. elongatus, B. amazonicus (omnivorous) and the $H$. edentatus (planktivorous) had presented levels of $\omega-6 / \omega-3$ ratio unsatisfactory to be considered the healthiest fishes, while the Amazonian fish within carnivorous, piscivorous and detritivorous eating habits can be considered great sources of balance between $\omega-6$ and $\omega-3$ fatty acids and thus healthy food sources at specific seasonal period.

The $P$. nigricans species (detritivorous fish) has an ideal $\omega-6 / \omega-3$ ratio only when the liver is evaluated as regardless of the season. Thus, as fish consumption is based mostly on the muscle tissue, in fact, it is not recommended to eat this fish, unless liver-based food can be explored. However, the other detritivorous fish studied here is S. insignis, which has shown optimal results for lipids from liver and muscle at drought season. The difference between the two detritivorous species was already explained by the distinct seasonal migratory habits, and can be supported by the agreement with the above mentioned S. insignis's, an increase of phospholipids content balanced with the decrease of neutral lipids at drought period. ${ }^{37}$ It is possible to relate these findings with eating habits, since those fish usually have more food abundance due to the increase of the flooded area, which contributed to the accumulation of energy reserves in the form of triglycerides rich in $\omega-6$, during the flooding period. Thus, during the drought season, the accumulation ends up being lower from $\omega-6$ fatty acids, which contributes to the reduction of $\omega-6 / \omega-3$ ratio. Furthermore, species with ideal $\omega-6 / \omega-3$ ratios in both tissues and periods of the year are $C$. monoculus and P. tigrinum (piscivorous fish), which means they are great fishes for consumption at any time of the year, as they often accumulate $\omega$-3 fatty acids in large amounts in their tissues to balance the $\omega-6$ amounts. While the carnivorous fish evaluated, the $P$. squamosissimus specie presented an ideal $\omega-6 / \omega-3$ ratio at any time of the year only when the dorsal muscles were evaluated, and can be considered an excellent source of $\omega-3$ lipids for human consumption, since the human consumption is based on the muscle tissue. Indeed, once more the popular knowledge showed itself accurate since the Amazonian population recommends piscivorous and carnivorous fish as the healthiest food sources.
Our data indicate the Amazonian's fish as beneficial lipid source and corroborate with the idea that diets enriched in fish oil $\omega$-3 fatty acids are good for health. ${ }^{50}$ This is also true because of the $\omega-6$ to $\omega-3$ ratio and knowing that Amazon fish lipids can change the lipid metabolism effectively lowering plasma low-density lipoprotein (LDL) and increasing high-density lipoprotein (HDL). ${ }^{51}$ When we interpret the data in the light of the crosstalk between the ecological environment and fish physiology, the species sharing the same food habits can have similar substrates for the endogenous synthesis of lipids, which seem to be used to attend the specific fish metabolism. ${ }^{52}$ Amazon fishes developed different adaptations to survive in the challenging environment of the region, such as migratory habits and mechanisms to deal with hypoxia exposure. ${ }^{53,54}$ Therefore, fish species may synthesize different lipids in response to seasonal changes according to the individual adaptations. Together, these facts explain why fishes within the same eating habit show a similar lipid profile (building blocks), but are sensitive to seasonal changes in terms of organ concentration (where lipid synthesis or storage is occurring) and consequent lipids composition (as a consequence of target organ metabolism).

\section{Conclusions}

Our findings suggest that the Amazonian fishes have lipidomes with high nutritional potentials to benefit human health, which can vary according to the tissue (mainly in amount) and are generally sensitive to the eating habits of the species (mainly in quality) and to seasonal changes. The observed high amounts of $\omega-3$ with a significant contribution of $\omega-6$ (mainly linoleic acid) reflect an ideal balance between these fatty acids, which associated with $\omega-6 / \omega-3$ ratio $<5: 1$ might be a perfect combination to promote human health. This is a relevant finding, considering that the local population consumes high amounts of almost all parts of these fishes (including muscle, head, eyeball, liver, and ova) and that these are acquired at a low cost, favoring the worldwide consumption.

\section{Supplementary Information}

Mapping of the fishes' capture, scheme of the number of fish exemplars captured; the ${ }^{1} \mathrm{H}$ NMR spectrum of total lipids, PLS-DA data on variable importance in projection (VIP), and PLS-DA VIP in heatmap format obtained for the lipids from the Amazonian fishes as supplementary information is available free of charge at http://jbcs.sbq.org.br as PDF file. 


\section{Acknowledgments}

FAPESP (Fundação de Amparo à Pesquisa do Estado de São Paulo), for the scholarships given to B. S. B. C. (PhD, process No. 2013/14707-9) and N. C. M. (scientific initiation, process No. 2014/11258-1), is kindly acknowledged. We also thank Maria de Nazaré Paula da Silva (Instituto Nacional de Pesquisas da Amazônia) who helped with the logistics for fish collection, and Micaela Andrea Gritti (Universidad Nacional Del Nordeste) who during her exchange stage helped with the total lipids extraction of a few samples.

\section{Author Contributions}

This work was part of the PhD work of Banny S. B. Correia, which collected the samples, extracted the lipids, performed the analysis by NMR, treated the data and wrote the paper; Gilberto G. D. Ortin and Natalia C. Mor as undergraduate students have helped with the extraction and preparation of samples; Maiara S. Santos has helped with the guidance and performing of quantitative NMR analysis; Raquel S. Torrinhas has contributed to the writing and discussion of the results; Adalberto L. Val has contributed with the guidance and management of the selection and collection of the samples, besides ideas, writing, and discussion of results; Ljubica Tasic as the supervisor has contributed to the ideas, guidance, writing, and discussion of the entire work.

\section{References}

1. Santos, G. M.; Ferreira, E. J. G.; Zuanon, J. A. S.; Peixes Comerciais de Manaus, $2^{\text {nd }}$ ed.; INPA: Manaus, Brazil, 2009.

2. Lobón-Cervia, J.; Hess, L. L.; Melack, J. M.; Araujo-Lima, C. A. R. M.; Hydrobiologia 2015, 750, 245.

3. Barthem, R. B.; Fabré, N. N. In A Pesca e os Recursos Pesqueiros na Amazônia Brasileira, $1^{\text {st }}$ ed.; Ruffino, M. L., ed.; Ibama/Provárzea: Manaus, Brazil, 2004, p. 268.

4. Junk, W. J.; Soares, M. G.; Aquat. Ecosyst. Health Manage. 2001, 4, 437.

5. Murrieta, R. S.; Dufour, D. L.; Ecol. Food Nutr. 2004, 43, 231.

6. Begossi, A.; Hanazaki, N.; Ramos, R. M.; Ecol. Appl. 2004, 14, 1334.

7. Silva, A. L.; Rev. Antropol. 2007, 50, 125.

8. Cheng, K.; Wagner, L.; Moazzami, A. A.; Gómez-Requeni, P.; Vestergren, A. S.; Brännäs, E.; Pickova, J.; Trattner, S.; Eur. J. Lipid Sci. Technol. 2015, 118, 862.

9. Simopoulos, A. P.; Exp. Biol. Med. 2008, 233, 674.
10. World Health Organization (WHO); Healthy Diet; WHO: Geneva, 2020. Available at www.who.int/en/news-room/factsheets/detail/healthy-diet accessed in June 2020.

11. Lunn, J.; Theobald, H. E.; Nutr. Bull. 2006, 31, 178.

12. Costa, I. D.; Petry, A. C.; Mazzoni, R.; Hydrobiologia 2018 , 809, 175.

13. Val, A. L.; de Almeida-Val, V. M. F.; Fishes of the Amazon and Their Environment Physiological and Biochemical Aspects; Springer: New York, 1995, p. 107.

14. Hurd, L. E.; Sousa, R. G. C.; Siqueira-Souza, F. K.; Cooper, G. J.; Kahn, J. R.; Freitas, C. E. C.; Biol. Conserv. 2016, 195, 118.

15. Wang, D. H.; Jackson, J. R.; Twining, C.; Rudstam, L. G.; Zollweg-Horan, E.; Kraft, C. E.; Lawrence, P.; Kothapalli, K.; Wang, Z.; Brenna, J. T.; J. Agric. Food Chem. 2016, 64, 7512.

16. Vasconi, M.; Caprino, F.; Bellagamba, F.; Busetto, M. L.; Bernardi, C.; Puzzi, C.; Moretti, V. M.; Lipids 2015, 50, 283.

17. Swanepoel, H.; Lues, J. F. R.; Venter, P.; J. New Gener. Sci. 2016, 14, 247.

18. Inhamuns, A. J.; Franco, M. R. B.; Batista, W. S.; Food Chem. 2009, 117, 272.

19. Rodrigues, B. L.; Canto, A. C. V. C. S.; Costa, M. P.; Silva, F. A.; Marsico, E. T.; Conte-Junior, C. A.; PlosOne 2017, 12, e0178898.

20. Petenuci, M. E.; Santos, V. J.; Gualda, V. J.; Lopes, A. P.; Schneider, V. A.; Santos Jr., O. O.; Visentainer, J. V.; J. Food Sci. Technol. 2019, 56, 1551.

21. Citil, O. B.; Kalyoncu, L.; Kahraman, O.; Vet. Med. Int. 2014, 936091.

22. Rude, N. P.; Trushenski, J. T.; Whitledge, G. W.; Hydrobiologia 2016, 773, 63.

23. Almeida, N. M.; Franco, M. R. B.; J. Sci. Food Agric. 2007, $87,2596$.

24. Almeida, N. M.; Visentainer, J. V.; Franco, M. R. B.; J. Sci. Food Agric. 2008, 88, 739.

25. Kaur, N.; Chugh, V.; Gupta, A. K.; J. Food Sci. Technol. 2014, $51,2289$.

26. Waitzberg, D. L.; Torrinhas, R. S.; Nutr. Clin. Pract. 2009, 24, 487.

27. Simopoulos, A. P.; Biomed. Pharmacother. 2002, 56, 365.

28. Bligh, E. G.; Dyer, W. J.; Can. J. Biochem. Physiol. 1959, 37, 911.

29. Mor, N. C.; Correia, B. S. B.; Val, A. L.; Tasic, L.; J. Braz. Chem. Soc. 2020, 31, 662.

30. Johnston, J. J.; Ghanbari, H. A.; Wheeler, W. B.; Kirk, J. R.; J. Food Sci. 1983, 48, 33.

31. Mestrelab Research; MestreNova, version 11.0.4; Mestrelab, Spain, 2017.

32. http://www.metaboanalyst.ca/faces/home.xhtml, accessed in June 2020. 
33. Jiang, X.; Huang, R.; Wu, S.; Wang, Q.; Zhang, Z.; J. Food Meas. Charact. 2018, 12, 1420.

34. Gurr, M. I.; Lipids in Nutrition and Health: A Reappraisal; Oily Press: Bridgewater, England, 2009.

35. Carvalho, F. M.; Acta Amazonica 1980, 2, 379.

36. Duarte, C.; Souza, V. S.; Nunes, C. O.; Amazon Sci. 2012, 1, 18.

37. Arrington, D. A.; Davidson, B. K.; Winemiller, K. O.; Layman, C. A.; J. Fish Biol. 2006, 5, 1347.

38. Braga, T. M. P.; Rebêlo, G. H.; Interciência 2014, 9, 659.

39. Popescu, R.; Costinel, D.; Dinca, O. R.; Marinescu, A.; Stefanescu, I.; Ionete, R. E.; Food Control 2015, 48, 84.

40. Li, J.; Vosegaard, T.; Guo, Z.; Prog. Lipid Res. 2017, 68, 37.

41. Erikson, U.; Standal, I. B.; Aursand, I. G.; Veliyulin, E.; Aursand, M.; Magn. Reson. Chem. 2012, 50, 471.

42. Nuzzo, G.; Gallo, C.; d'Ippolito, G.; Cutignano, A.; Sardo, A.; Fontana, A.; Mar. Drugs 2013, 11, 3742.

43. Kaçar, S.; Başhan, M.; Oymak, S. A.; Grasas Aceites 2018, 69 , e242.

44. Netleton, J. A.; Omega-3 Fatty Acids and Health, $1^{\text {st }}$ ed.; Springer: Boston, MA, USA, 1995.
45. Ferreri, C.; Chatgilialoglu, C.; Expert Rev. Mol. Diagn. 2012 , $12,767$.

46. Calder, P. C.; Biochim. Biophys. Acta 2015, 1851, 469.

47. Flock, M. R.; Harris, W. F.; Kris-Etherton, P. M.; Kris-Etherton, P. M.; Nutr. Rev. 2013, 10, 692.

48. Lu, H.; Hong, H.; Luo, Y.; J. Food Sci. Technol. 2016, 1, 11, DOI 10.25177/JFST.1.1.2.

49. Serhan, C. N.; Yacoubian, S.; Yang, R.; Annu. Rev. Pathol. 2008, $3,279$.

50. Silva, V.; Barazzoni, R.; Singer, P.; Nutr. Clin. Pract. 2014, 29 , 63.

51. Souza, F. C. A.; Garcia, N. P.; Sales, R. S. A.; Aguiar, J. P. L.; Duncan, W. L. P.; Carvalho, R. P.; Rev. Nutr. 2014, 27, 97.

52. Muro, E.; Atilla-Gokcumen, G. E.; Eggert, U. S.; Mol. Biol. Cell 2014, 25, 1819.

53. MacCormarck, T. J.; Lewis, J. M.; Almeida-Val, V. M. F.; Driedzie, W. R.; J. Exp. Zool. 2006, 305A, 363.

54. Sloman, K. A.; Baker, D.; Winberg, S.; Wilson, R. W.; Anim. Behav. 2008, 76, 1279.
Submitted: February 7, 2020

Published online: June 29, 2020 